work as professor of medicine in the University of the Witwatersrand; Dr. L. King, for work on geomorphology, surface geology and other geological subjects in New Zealand and in South Africa.

\section{Fourth Congress of the International Scientific} Film Association

THE Fourth Annual Congress and Festival of Scientific Films of the International Scientific Film Association was held in Florence during October 14-22. The following officers were elected for 195051 : President, John Maddison (Great Britain); Vice-Presidents, Luc Haesaerts (Belgium) and Jan Korngold (Poland); Honorary Secretary, Jean Painlévé (France); Honorary Treasurer, Mario Ponzo (Italy). Among the most important decisions reached during the Congress were those dealing with the setting up in Brussels of the first International Reference Film Library of scientific films; the adoption of a standard system of recording, and interchanging internationally, information about scientific films; and the production by international effort of a film on meteorology, for which a first treatment has already been prepared. Valuable progress on the part of the Research Committee and the Medical Committee was reported. Great Britain was represented by a delegation of ten members, including representatives of the Scientific Film Association of Great Britain, the British Council and the Royal Photographic Society. Great Britain also contributed about thirty per cent of the total of some one hundred and twenty films on $\mathrm{a}$ wide variety of subjects which were shown. The technicel excellence and the scientific qualities of all of the films, in comparison with those shown in previous years, have given proof of a considerable advance in the production of this type of film.

\section{Conference on Evolution and Education}

A CONFERENCE on "Evolution and Education", sponsored by eleven scientific and social organiza. tions, will be held in the Chemistry Lecture Theatre, University College, London, during December 8-9. The following papers (some followed by discussion) will be read: "The Evolutionary Process" (Dr. Julian Huxley); "The Teaching of Evolution" (Miss M. L. Johnson, Miss E. L. Buckley, Mr. R. Weatherall); "School Broadcasting and Evolution" (Mr. Richard Palmer); "Evolution and Christian Belief" (Dr. W. H. Thorpe); "Modern Views on Evolution in the Light of Recent Advances in Embryology" (Dr. G. R. de Beer). Further information can be obtained from the British Social Biology Council, Tavistock House South, Tavistock Square, London, W.C.1.

\section{Conference on Homes and the Family}

The British Committee of the International Union of Family Organizations, which comprises seventeen scientific and social institutions, is arranging a conference on "Homes and the Family" to be held on November 23 at the Caxton Hall, London. The first session will deal with "The Housing Needs of the Family", and will be held under the chairmanship of Prof. Winifred Cullis. Mrs. Graham-Bryce will take the chair at the second session, which will deal with "Housing and Health : the Medical and Moral Effects of the Problem on the Family". Further information can be obtained from the Honorary Secretary, British Committee of the I.U.F.O., c/o British Social Biology Council, Tavistock House South, Tavistock Square, London, W.C.1.

\section{Scottish Postgraduate Agricultural Scholarships}

The Department of Agriculture for Scotland has awarded the following postgraduate agricultural scholarships, commencing this year and tenable as shown: Husbandry, A. O. Ballantyne (University of Edinburgh), H. G. Livingston and J. W. Stoddart (University of Reading); Agricultural Economics, G. F. B. Houston and S. G. Strachan (Agricultural Economics Research Institute, Oxford); Statistics, St. C. S. Taylor (University of Edinburgh). The Department has extended five current awards for a further year, as follows : Husbandry, A. G. Campbell (Massey Agricultural College, Palmerston North, New Zealand), C. D. Reekie (Cornell University), and Miss M. I. Ore (University of Edinburgh); Agricultural Engineering, G. T. Ward (King's College, Newcastle upon Tyne); Agricultural Economics, K. A. Ingersent (University of Minnesota).

\section{Lenzites thermophila Falck}

DR. W. H. WinkrNs, of the Mycology Laboratory, Oxford, writes : "Mr. K. St. G. Cartwright, of the Forest Products Research Laboratory, Princes Risborough, has directed my attention to the name Lenzites thermophila Falck 75 in Dr. H. S. Burton's communication published in Nature of September 30, p. 570. In 1946 I received from the Forest Products Laboratory three cultures labelled respectively by that Laboratory, $L$, thermophila Falck $75, L$. thermophila Falck 75A and L. trabea (Pers.) Fr. 108. In view of this $I$ ignored the note by Cartwright (Trans. Brit. Mycol. Soc., 16, 304 ; 1931) and the confirmation by Mounce and Macrea (Canad. J. Res., 14, 215; $1936)$ that $L$. thermophila Falck was synonymous with Lenzites trabea (Pers.) Fr., which latter name has priority. I apologize to Dr. Burton for having misinformed him on this point."

\section{Announcements}

Mr. JAMES WrukIE, secretary of the Carnegie United Kingdom Trust, has been elected president of the Library Association for 1951 in succession to H.R.H. the Duke of Edinburgh. The next annual conference of the Association will be held in Edinburgh during June 4-8, 1951.

Tres Gulland Laboratory of the Scottish Seaweed Research Association at Inveresk Gate, Musselburgh, will be officially opened by the Right Hon. Hector McNeil on November 24.

THE first annual report of the Commonwealth Scientific and Industrial Research Organization, for the year ended June 30, 1949 (pp. 137; Canberra : Commonwealth Government Printer, 1949 ; 7s. 9d.), of which a multilithographed copy was tabled in Parliament by the Organization's Minister last year (see Nature, April 29, p. 677), has now been printed, and copies are available for distribution.

A coURSE of four lectures on ecology, arranged by the Association of Agriculture, will be held at the University of London Institute of Education, Malet Street, London, W.C.1, two lectures being given during each of the mornings of December 9 and 16, commencing at $10 \mathrm{a.m}$. The emphasis of the course will be on ecology in agriculture and in school teaching, and the speakers will be Sir James Scott-Watson, Mr. A. P. Weller (Oxford Education Committeo), Dr. A. S. Thomas (Nature Conservancy) and Prof. J. E. Nichols (Aberystwyth). The fee for the course is $2 s$. Applications should be sent to the general secretary of the Association of Agriculture, 238-40 Abbey House, 2 Victoria Street, London, S.W.1. 